\author{
G.G. Shinet ${ }^{1}$, G.A. Zhadigerova ${ }^{2,}$, A.Y. Yesbolova ${ }^{3}$, R.K. Andarova ${ }^{2}$, E.E. Zhussipova $^{3}$ \\ ${ }^{1,2,3}$ Miras University, ${ }^{4}$ Karagandy University of the name of academician E.A. Buketov, Kazakhstan, \\ ${ }^{5}$ M. Auezov South Kazakhstan State University \\ 'gshnet@bk.ru, 2gulshat_zhadigerova@mail.ru,yesbolova@gmail.com, \\ 4ARK_Roza@mail.ru, ${ }^{5}$ elmira_zhusipova@mail.ru \\ ${ }^{1}$ https://orcid.org/0000-0002-4042-2297, ' https://orcid.org/0000-0001-8529-8659, ' https://orcid.org/0000-0001-9503- \\ 9482, ${ }^{3}$ https://orcid.org/0000-0003-4847-6422, ${ }^{4}$ https://orcid.org/0000-0001-7363-8214 \\ ${ }^{1}$ Scopus Author ID: 57189689439, ${ }^{3}$ Scopus Author ID: 56682061900
}

\title{
Role and development of personal husbandries in solving employment issues in the region
}

\section{Abstract}

Object: The content of the article is intended for agriculture to contribute to the solution of a social problem - employment of the population.

Methods: It provides for the functioning of the population's economy in the agriculture of the Republic of Kazakhstan and its share in the production of agricultural products today. It describes the principle of operation, quantitative indicators of population farms, the share in the production of agricultural products. Quotes about the conduct of numerous studies on the self-employment of the agricultural population.

Results: Farms of the population explained the current situation in agriculture, which has its own share in the employment of the rural population. However, there are no complete targeted comprehensive studies for the study of rural employment. In this regard, the validity of the study and analysis of this topic is given. By providing quantitative data, the public has proved that agriculture has a significant share in the production of agricultural products.

Conclusions: This covered the employment of the rural population, which in the competition can be found in the interpretation of their income. This explains that rural populaton isself-employed and earns on household farms.

Keywords: agriculture, agricultural enterprises, public, private subsidiary farms, peasant (farm) farms, self-employment, employed, agricultural enterprises, livestock, crop production.

\section{Introduction}

During the transition to a market economy and with the decline in production in the agro-industrial complex, the problem of employment and income of the rural population has sharply worsened. Due to the lack of new jobs and extremely limited scope of employment in other sectors of agriculture, a significant part of the rural population of working age was forced to work on their own farms. Population farms (personal subsidiary farms) proved to be the most stable and viable form of management in the agricultural sector, which is due to the historically established way of rural life, and, in addition, the most complete implementation of economic independence and responsibility (Shinet, Myrzaliev, Ydyrys, 2016).

The role of households in rural areas has increased significantly in recent years. The level of development of this sector of the economy depends not only on the provision of rural residents with food, but also on the employment rate of labor resources. The decrease in the unemployment rate and the growth of social protection for the unemployed dictate the need to develop and implement a program to support households, adopt special programs that will provide social security for those employed in this sector of the economy, if they do not have another job.

The lack of an effective system for regulating employment in agriculture has a negative impact on rural demography, working conditions and social status of rural workers, and creates difficulties in providing the agro-industrial complex with qualified personnel.

As an integral part of a multi-layered agricultural economy, households provide employment, increase the income of rural families, and make a significant contribution to food security. As an economic entity consisting of one or more individuals United by relations of reproduction and realization of human potential,

\footnotetext{
*Corresponding author.

E-mail address: gulshat_zhadigerova@mail.ru
} 
living together and leading a common economy, the main goal is to meet the socio - economic needs of its members.

\section{Literature Review}

Many aspects of the problem were considered in the works of A.Smith, D.Ricardo, FR.Quesnay, W.Jevons, A.Pigou, J.Keynes and others. Issues of employment and the formation of the labor market are considered in the works of V.A.Bogdanovsky, JI.B.Bondarenko, B.P.Pankov, A.B.Soskiev, Yu.N.Shumakov, A.B. Shuvaev, V.E. Gimpelson, R.I.Kapelyushnikov, S.Ivanov and others. Theoretical and practical aspects of cooperation in the agricultural sector are studied in the works of A.V.Chayanov, M.I. Tugan-Baranovsky and other Russian scientists and cooperative figures of the XX century. Certain aspects of this problem are widely covered in the works of A.P.Zinchenko, F.K.Shakirov and N.Ya.Kovalenko. Their research provided a good basis for research in this area.

Despite the large number of studies devoted to the problems of employment of the rural population and the study of the development of farms, we note that integral comprehensive research on rural employment, especially employment in the economy of the population is currently clearly insufficient, which makes the stability of the agricultural economy vulnerable. There is no scientifically-based concept for the formation and regulation of rural employment, and the positive experience of creating sustainable models of rural employment in households has not been sufficiently studied (Myrzaliev, Shinet, 2016).

\section{Method}

Various methods were used during study. The study examined the stages of various foreighn models of development of the personal husbandries in the field of agriculture. When analyzing the development of alternative personal husbandries abroad, the current state and support measures, casual methods of analysis were used.Consolidation, logical and comparative methods have been used effectivelyin the study of differences and genera similarities among the public in several countries. Economic and statistical methods are widely used in the analysis and assessment of the current state of economic equivalents of the population as well as trends in development, abstract and logical method-in identifying problems and developing proposals for measures of state regulation and support of householdequivalents abroad.

\section{Results}

The economic basis of the economy of the population is private ownership of factors of production: means of production, land, labor, etc. The family itself and its members are both producers and consumers of manufactured products. The peculiarity of households is that they allow using the labor opportunities of almost all categories of the rural population. Characteristic features of the functioning of households are freedom of economic activity, independence in making economic decisions and full economic responsibility for the results of their work. In official statistics, household income is not taken into account, because for objective reasons there is no accounting for their economic activities. At the same time, the activities of households bring considerable benefits to society: first, the subjects of economic activity are self-employed; second, the population independently meets their needs for food. Under these conditions, the state saves resources for its own business activities by providing support to other industries. It should be noted that the role, place of population farms and their significance in industrial and social relations are ambiguous and constantly change depending on objective and subjective factors. So, if earlier the purpose of the existence of households was to provide rural residents mainly only with food, now the functions of households have significantly expanded, and in addition to economic, they have begun to solve social and environmental problems. Due to the naturally formed and in recent years deepened division of production between agricultural organizations and farms of the population, especially clearly expressed in crop production - the vast majority of potatoes, vegetables, fruits are produced by the population, and grain, technical, forage crops - by agricultural organizations. The ratio of these categories of farms and the dynamics of their share in gross agricultural output is influenced, and will continue to be influenced, by the productivity and gross harvest of crops prevailing in a particular category of farms, the labor intensity of production. Being a special form of economic life in rural areas, the population's farms are traditionally supplemented by agricultural organizations. Therefore, it is wrong to set them against each other. Since the population's farms participate in the social division of production and labor in the agricultural economy, the situation with these farms cannot be considered outside of these links with other sectors and socio-economic forms of management in the agricultural sector and the economy as a whole. All this increases the interest in the population's farms, their socioeconomic and resource potential as a subject and object of management. In our opinion, the potential of the population's farms should be understood as a system of interrelated, mutually dependent and interacting factors that ensure effective and sustainable development of the population's farms, both in modern conditions 
and in the future. It is quite clear that due to the naturally developed and in recent years deepened division of production between agricultural organizations and households of the population, especially clearly expressed in crop production, the vast majority of potatoes, vegetables and fruits are produced by the population, while grain, technical and fodder crops are produced by agricultural organizations. The ratio of these two categories of farms and the dynamics of their share in gross agricultural output is influenced, and will continue to be influenced, by the productivity and gross harvest of crops prevailing in a particular category of farms, the labor intensity of production. The division of production between agricultural organizations and households is not limited to differences in product specialization, both in the country as a whole and in individual regions. Marketability and self-sufficiency are also taken into account. Agricultural organizations directly contribute to the country's food supply, and the population's farms meet local food needs. During the study period, the overall role of small business has decreased, especially in the development of households (Yesbolova, Ibraimova, Mergenbaeva, 2016).

A significant increase in production on household and other plots of private farms can be explained by the response of the population to the deterioration of the economic situation in agricultural production, the reduction or even complete elimination of collective production. The process of moving the labor activity of the rural population from the public sector to the private sector is mainly due to: - a decrease in wages and their share in the total family budget; - lack of alternative employment, i.e. the narrow scope of employment in rural areas. Employment in a personal subsidiary farm has become a form of self-employment and provides almost half of the total family income.

Any work activity of a person is determined by motivation, which reflects real needs, interests, values and value orientations. It creates real reasons for people's actions, achievements, and possible ways to meet their needs and interests. When forming a motive, a person evaluates their capabilities and weighs the significance of various needs and their priorities. For unemployed citizens, the need for recognition and prestige takes a back seat. The lack of a permanent income, family and children put the first place motives for providing, and to survive the adverse situation in the absence of alternative forms of employment, unoccupied citizens are forced to choose self-employment in a personal subsidiary farm (in the household) (Valiev, Koshlich, Mussayeva, 2018).

The main incentive for the population's farms is the production of basic food products for their own consumption. Households mostly generate income in kind, and if part of the output is sold, then in cash. Thus, the population's farms partially compensate for the deficit of funds for the reproduction of labor and the population as a whole, which has developed due to low wages in rural areas. Farms of the population have limited opportunities for Autonomous development and can develop mainly through integration with large-scale production. The development of the population's economy depends on the financial condition of agricultural organizations. In economically strong farms, the share of household income in total family income is significantly lower than in insolvent agricultural organizations. However, in a crisis, peasant farmsteads become not only a condition for self-sufficiency in food, but also the main source of income, a means of survival for rural residents (Yesbolova, Mergenbaeva, Abdikerimova, Kydyrova, 2016).

The development of agriculture in the country is directly related not only to the employment of certain types of crop and animal husbandry, depending on the climatic and soil conditions on its territory, but also to the strict implementation of targeted trends of agricultural producers and well-formed legal norms. Turkestan region is one of the most advanced in the production and processing of agricultural products, depending on the geographical location and climatic features. Since it is the hottest in terms of weather conditions, the main center of cotton growing, as well as an intensive irrigated agricultural and livestock zone in the Republic.

Turkestan region is one of the largest regions of the Republic, bordering on the East with Zhambyl region, in the North with Karaganda region, in the West with Kyzylorda region, in the South with the state of Uzbekistan. The territory of the region is 116.2 thousand square kilometers, and the population - a zone with a population of about 2.0 million people.

According to the administrative-territorial structure of the region, there are 7 cities, 15 districts, and 836 villages (table 1). The regional center is the city of Turkestan, which has a history of more than 1500 years. Since the second half of the XX century, it has become a major industrial, educational and cultural center, the center of domestic and foreign tourism.

Currently, in the Republic of Kazakhstan, the population tends to actively develop farms. As of January 1,2019 , there were 254,490 households in the Turkestan region.

Agriculture is an integral part of the agricultural economy. It is based on the use of resources and labor potential of rural families. To determine the role of the public economy in the development of agricultural production, it is necessary to study quantitative data on the development of the population's economy in certain areas. 
The population of the Turkestan region was 1973.3 thousand people, the average annual number of rural population in 2018 was 1574.2 thousand people. In other words, this is $80.5 \%$ of the region's population. This rural population as of 2018 , lives in 932 villages.

The economic function of the population's economy is one of the main producers of food products of the rural population, an additional reserve for increasing food resources. From a social point of view, the public is one of the sources of income growth for the rural population and provides employment for a significant part of it. At the expense of the population's economy, most of the family's income is formed, and agricultural labor education of the younger generation is formed. In addition, the farms of the population make it possible to effectively use the additional labor resources of the village: the Work of the elderly, teenagers, households and the unemployed.

Table 1. Administrative divisions for 2018

\begin{tabular}{|l|c|c|c|c|c|c|c|}
\hline \multirow{2}{*}{ Regions } & $\begin{array}{c}\text { Territory, } \\
\text { thousand. } \\
\text { square, } \mathrm{km}\end{array}$ & \multirow{2}{*}{ Areas } & in total & $\begin{array}{c}\text { the field } \\
\text { strength values }\end{array}$ & $\begin{array}{c}\text { district- } \\
\text { value }\end{array}$ & $\begin{array}{c}\text { settle- } \\
\text { ments }\end{array}$ & villages \\
\cline { 4 - 8 } & 2724,5 & 177 & 87 & 38 & 47 & 26 & 6693 \\
\hline Republic of Kazakhstan & 116,2 & 13 & 7 & 1 & 6 & - & 932 \\
\hline
\end{tabular}

The structure of gross output of agricultural, forestry and fisheries products (services) by farm category is shown as a diagram in figure 1 . The diagram clearly shows the volume of gross output of agricultural, forestry and fisheries products (services) in the category of population economy.

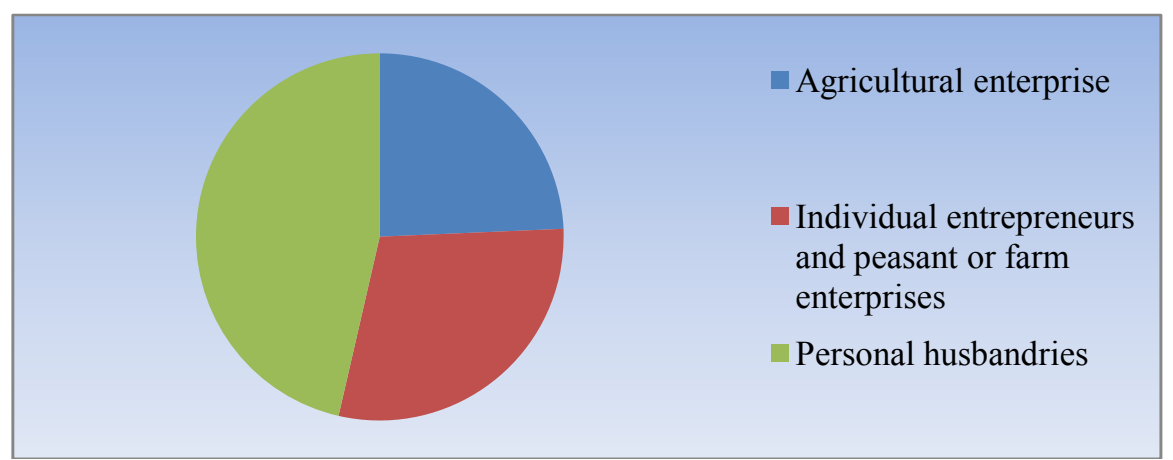

Figure 1. Structure of gross output of agricultural, forestry and fisheries products (services) by category of farms Note-prepared by the author based on the source

In a multi-faceted economy, the most important place in agricultural production is occupied by farms of the rural population. This is due to the insufficient level of agricultural production in rural areas, the limited branches of labor of the rural population and the functioning of the personal economy due to low monetary incomes of rural families. They maintain their positions both during the period of economic growth and during the crisis of agricultural production. Therefore, in our opinion, they should be considered as a stable component of the agricultural sector. They will continue to play an important role in the formation and maintenance of rural society (Hachataryan, Kazaryan, 2020).

In the post-Soviet space, traditionally all households in rural regions were considered owners of land plots near their homes. Today, it is impossible to imagine the life of the rural population without farms formed under the household economy. Due to the fact that the rural population meets the needs for food, it has increased and even grown.

In recent decades, the role of households has increased. In the agro-industrial complex, the population becomes the organizational and legal form of production of the most flexible, sustainable and purposeful agricultural products (Avarskij, Gasanova, Gadzhieva,2016).

In recent years, a significant role in the agricultural economy is played by households. Farms of the population have always been a source of life support for the rural population. But the essence of the population's farms not only provides the rural population with food necessary for life, but also during the agrarian reforms, they became a source of additional income as a result of the work of the rural population. The form of preserving the social status achieved in the pre-crisis period for the rural population is the result of the factor of reducing poverty in rural areas (Yesbolova, Maciejczak, Ibraimova, Akhelova, 2016). 
Currently, agriculture is an integral part of the agricultural sector. Of course, the main share in the formation of the food Fund should be the social method of production. However, this industry has been reducing agricultural production every year since the beginning of economic reforms. Farms the population has quickly adapted to the new conditions and annually increases both the number of livestock and production.

Farms of the population specialize mainly in raising animals. In the following table (table 2), as of January 1, 2018, the following types of livestock are developed by volume: sheep, cattle, horse, camel, poultry.

Table 2. The number of varieties of cattle breeding in the farms of the population of the Turkestan region (thousand heads) and their share in all categories of farms, as a percentage

\begin{tabular}{|c|c|c|c|c|c|c|c|c|c|c|c|}
\hline \multirow{3}{*}{$\begin{array}{c}\text { The name } \\
\text { of the } \\
\text { show } \\
\text { signal }\end{array}$} & \multicolumn{10}{|c|}{ Years } & \multirow{3}{*}{ 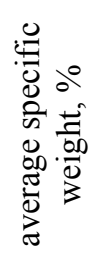 } \\
\hline & \multicolumn{2}{|c|}{2014} & \multicolumn{2}{|c|}{2015} & \multicolumn{2}{|c|}{2016} & \multicolumn{2}{|c|}{2017} & \multicolumn{2}{|c|}{2018} & \\
\hline & 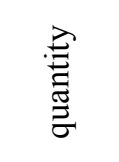 & 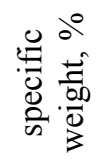 & $\begin{array}{l}\text { 总 } \\
\text { 壳 } \\
\text { 己े }\end{array}$ & 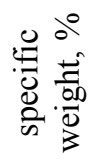 & 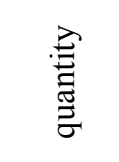 & 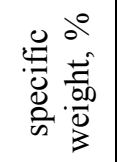 & 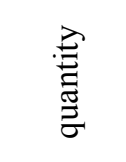 & 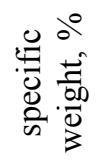 & $\begin{array}{l}\stackrel{\vec{E}}{\vec{E}} \\
\text { 奇 }\end{array}$ & 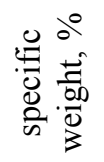 & \\
\hline cattle & 703,6 & 91,2 & 708,5 & 90,2 & 743,2 & 89 & 806,0 & 88 & 857,0 & 86,2 & 88,9 \\
\hline cows & 295,5 & 91,8 & 315,7 & 90,5 & 328,9 & 89,06 & 362,5 & 87,7 & 394,5 & 88,1 & 89,4 \\
\hline $\begin{array}{l}\text { sheep and } \\
\text { goats }\end{array}$ & 2938,2 & 79,5 & 2963,5 & 80,1 & 2993,7 & 79,5 & 3124,9 & 78,2 & 3119,1 & 76,3 & 78,7 \\
\hline horses & 173,8 & 84,4 & 179,6 & 68,1 & 223,4 & 75,2 & 250,0 & 84,2 & 269,5 & 84,2 & 79,2 \\
\hline camel & 12,1 & 56,8 & 12,1 & 54 & 12,7 & 49,3 & 12,5 & 48,2 & 13,5 & 48,2 & 51,3 \\
\hline poultry & 1141,0 & 68,7 & 1145,5 & 67,1 & 1106,5 & 65,1 & 1163,6 & 61,7 & 1207,1 & 58,9 & 64,3 \\
\hline
\end{tabular}

The number of livestock varieties belonging to the population's economy on a regional scale and its share in all farms in percentage terms are listed. According to the average report for the last five years, the largest number of livestock on a regional scale is accounted for by households. Thus, of cattle $-88.9 \%$, cows $-98.4 \%$, sheep and goats- $78.7 \%$, horses $-79.2 \%$, camels- $51.3 \%$, poultry- $64.3 \%$ are managed by the population.

Based on the data of this table, the number of livestock and their specific weight in all categories of farms of the population of the Turkestan region are presented in the form of diagrams according to figure 2 .

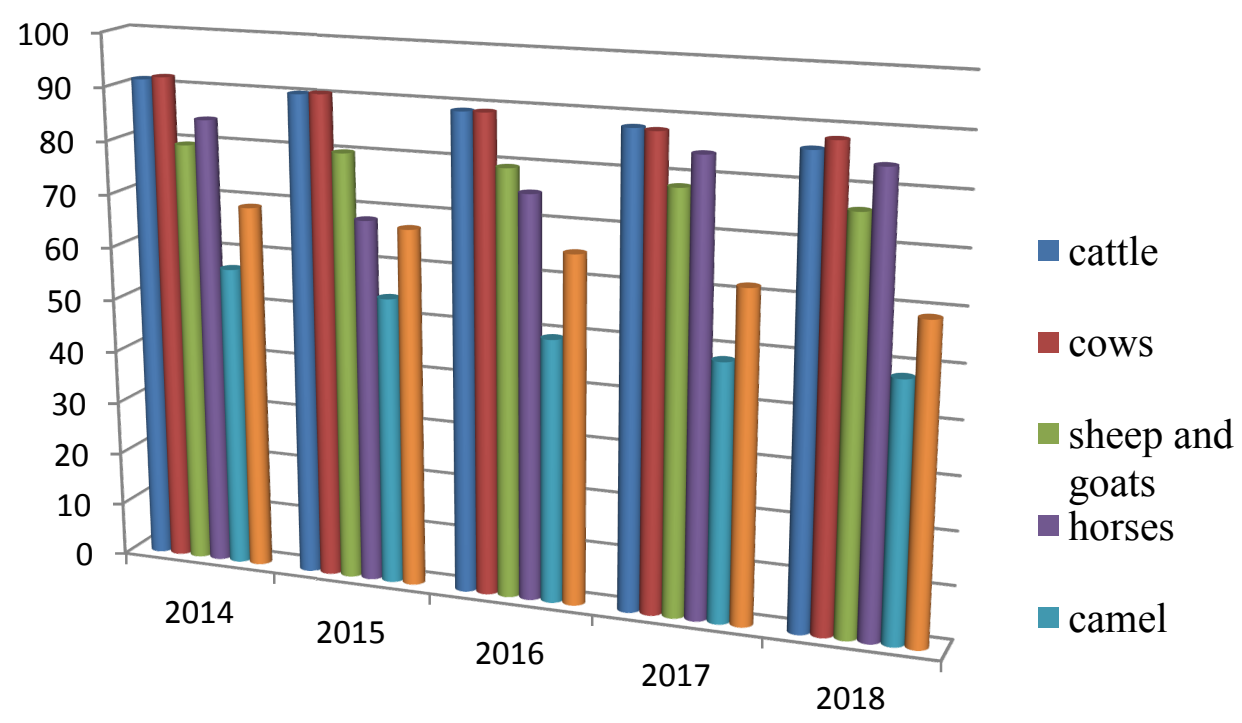

Figure 2. Proportion of livestock population in the Turkestan region in all categories of farms

Note-prepared by the author based on the source

In the course of studying the economy of the population, it should be noted that along with the analysis of changes in its statistical indicators, these changes also affect the social sphere. Thus, in the 10 years from 
1992 to 2002, rural families were able to expand their economy by increasing production. In doing so, they eased the burden of "uselessness" in the main job and held back the accelerated decline in living standards. However, this strategy of strengthening the family economy did not implement everything. It is this public that is reflected in the classification of the rural population by economy. Among the "outsiders" found those who could not increase the load of their personal farms and did not want to increase

In recent years, the lumpen group was known, consisting of people who do not work both in their own economy and in the enterprise. They see random success and believe in help from the state. There is a demand for them from owners of farms of medium and large population as temporary workers. Owners of these farms are interested in prompt and relatively low-cost harvesting, forage, firewood. This situation is observed in all regions of the Republic, i.e. farm owners of the population hire workers from among their villagers for one-time work related to land cultivation and harvesting. In some cases, the relationship between owners and temporary employees was of a salaried nature.

The unemployed in rural areas formed their own adaptation model without the support of any state and without the participation of any employer. Speaking about the employment of the rural population, we should focus on two opposing trends. On the one hand, there is an increase in agricultural production and the activation of animal husbandry, which has increased the demand for the rural population and returned some of the forced unemployed to production. On the other hand, the head of the agricultural enterprise began to regulate labor relations, applying management methods in the composition of previously unused personnel.

This has led to the arrival of urban investors in rural regions, who buy shares in enterprises and invest in the development of production. And new owners, first of all, face the issue of efficiency, so they close good businesses and decide to lay off employees. Thus, the negative phenomenon of unemployment becomes active .

The consequences of the movement of urban capital to rural areas are both positive and negative. The rural population is experiencing certain risks. This threatens not only the preservation of normal jobs, but also the preservation of large-scale agricultural production in rural areas. As a result, urban investors acquire the production base of agricultural enterprises ' infrastructure. Even ends with the mass sale of liquid assets. Then the new owners will feel the accuracy of attempts in rural areas to get financial results as a matter of urgency. As a result, the rural population loses everything - they become unemployed and lose the ability to conduct large-scale subsidiary farming (Shinet, 2015).

Thus, the growth of the population's farms from the state's agricultural policy depends on the socioeconomic situation of the village, negative trends, including: due to unemployment, the population's farms lead to the use of themselves as an additional source of employment and family income. In our view, one of the goals of the state agricultural policy is to encourage the creation of cooperatives, provide legal support, allocate the necessary funds and prioritize support for such initiatives.

Also, in our opinion, it is necessary to review the strict financial policy in relation to agro-industrial production. State regulation of the agricultural market, especially price policy, plays an important role.

\section{Discussion}

Along with these social issues, the effective development of the population's economy is directly related to a number of issues of an economic and organizational nature, so there are problems that are faced daily, for example:

1. Difficulties of the public economy arising in connection with sales, storage, transportation and marketing of products.

One of the priority factors that negatively affect the economic management of the population is the sale of their products. The main constraints here are not the lack of demand for agricultural products and food, but the lack of sales infrastructure. Therefore, small producers are forced to sell their products to intermediaries at their own cost.

Profit from its implementation is received by speculators, but nothing from this will go to the budgets of all levels. The established intermediary structure encourages and buys products at reduced prices, which prevents the population from freely selling their products. This issue is related not only to the lack of a functioning sales structure that meets the interests of producers, but also to the lack of infrastructure for primary processing, storage and transportation of agricultural products. In order to eliminate this negative situation, it is necessary to develop the sphere of trade and intermediary services in a comprehensive manner and to expand contract relations with agricultural enterprises and processing enterprises (Grigoruk, Umbitaliev,2017). 
Small-family farming will not increase the competitiveness of domestic food products, both in the world market and in the domestic market, compared to imports. Because farmyards are not of the type where modern high-performance technologies are used. For this reason, they produce products with high cost and low quality.

The economy of the population is closely connected with newly organized economic structures with local governments. They are combined with these structures in General with localities and rural districts. However, the amount of aid that was previously traditional has been significantly reduced, since many agricultural enterprises (especially small ones) have themselves found themselves in a difficult financial situation, and the population's farms have not been able to provide their workers with a resource base.

The following types of assistance can be considered as a set of measures required by households:

- organization of storage, acquisition, sale of products;

- preparation and full provision of feed for livestock;

- allocation and use of pastures for grazing;

- organization of providing services for the use of pastures;

- veterinary and agronomic assistance;

- transport services (Plotnikov, 2013).

To provide these types of assistance, the following measures must be taken:

- creation of on-farm departments aimed at servicing the population at large economic capacities of agricultural enterprises to serve the population's farms;

- - their relations with enterprises should be built on the basis of long-term contractual relations that enshrine the rights, duties and responsibilities of the parties;

- otherwise, the organization of cooperatives created by households of the population to serve households of the population.

The advantages of cooperatives are the combination of a shared Fund of land plots. Cooperatives are created with local organizations for the purpose of mutual land processing, forage harvesting,and livestock grazing.

- difficulties arising from the unavailability of financial resources to households.

2. Difficulties arising from the unavailability of financial resources to households

At the beginning of the reforms, the state supported the direction of creating a multi-industry economy. And this direction is practically implemented. The equality of rights of all objects of agricultural producers is declared. This position has not been implemented, i.e. the population has never received state financial support in comparison with peasant farms (without taking into account the micro-credit provided to lowincome families). Of course, this is discrimination over the household. In our view, the ideological and political atmosphere of family farming should be changed. Its essence is that the measures of state support will be applied to households on a par with large objects of management. Households that participate in government programs must have access to preferential loans, fertilizers and chemicals, seed and breeding stock, and so on.

The unavailability of financial resources that negatively affect the development of the economy of the population is directly related to the required high-level collateral for obtaining a loan. The lack of necessary financial resources leads to the use of simple technologies in the production of small businesses, morally and physically worn-out equipment and manual labor. This, in turn, reduces the efficiency of agricultural production and the small commodity sector of the agro-industrial complex(Kojtanova, Zholmuhanova, Al'peisova,2017).

3. Difficulties arising in connection with the legal instability of the functioning of households.

This is a question that arises from the above-mentioned question, i.e. in connection with the financing of the economy of the population. The development of banking operations in the retail services market is directly due to a fairly high level of risk. This is directly related to the fact that people who are engaged in household activities are retired or do not have permanent jobs. Practically, banks are ready to provide villagers with a loan. Here, the main problem is not specifying the population's farms as an object of credit, whether they are a legal entity or an individual, an entrepreneur or a farm owner. For creditor banks, you need to issue all the necessary documents, the collateral base, the presence of a pledger, that is, everything. And those who are engaged in households of the population do not have any of the above, or official income. Therefore, the owner of the farm must not legalize their income if they want to get a loan. It, in turn, must be registered with the tax Committee (Fava Fabio., Gavrilescu, 2012). 
One of the most pressing issues in agriculture is not only the deterioration of soil fertility in rural pastures, but also the systematic development of farmland. In General, large amounts of agricultural pasture land have been transferred to long-term leases to legal entities and individuals. They, in turn, do not conduct any type of agriculture on the leased land, but rent it out to another third party and receive rent as a source of income. This situation, in addition to social inequality, denies the inflow of investment in agricultural production. In this regard, it is necessary to make legislative changes to the conditions of development, including irrationally used agricultural land, pastures and hayfields (Mizanbekova, Uspanova, Kunanbaeva, D. (2018).

Today, the main direction of agricultural policy is the sustainable development of rural regions. As a sustainable rural development you can call them moderate socio-economic development, increase of agricultural production, full employment of the rural population, increasing their life and improving the efficiency of agricultural production, rational use of land (Yesbolova, Ibraimova, Zhadigerova, Sametova, 2014).

The state and development of agriculture in the region contributes to the sustainable development of the rural community, improving the level and quality of life of the rural population, and preserving the ecological balance in rural areas. Since the population plays an important role in the agro-industrial production system, it is necessary to solve the problems that arise for the development of their future opportunities. Therefore, it is necessary to carefully consider all the conditions that are necessary for the proper functioning of the public economy, to develop and implement mechanisms of a new Mature type.

Ensuring the sustainable development of the territory is directly related to the organization of cash flows sufficient to support the life potential and development of rural areas. In other words, this type of organization involves the simultaneous use of all sources of sustainable development. For example, by using national and regional funding, as well as using the opportunities of innovative and traditional businesses based on the internal resources of the territory (Andarova, Zhadigerova,Narkulova, 2019 ).

\section{Conclusion}

The main directions of increasing the profitability of production of households in rural regions are:

- creation and development of measures for storage and processing of products;

- creating conditions for selling products to manufacturers at favorable prices;

- coverage of households in the agricultural machinery market at affordable prices;

- provision of material and technical services on a leasing basis;

- cheapening and improving the quality of agricultural and veterinary services.

As a result, speaking about the main indicators of agriculture in the region, we discussed the indicators of agricultural production in the region. Based on the current situation, we have justified the importance of taking and implementing measures necessary to improve the work of the population engaged in the national economy, contributing to solving the main problems of the national economy, increasing production volumes. Thus, the self-employment of households will be stable and will increase the number of people employed in their own farms.

In conclusion, we note that the development of self-employment in households is one of the most important ways of combating unemployment in rural areas, it helps to change stereotypes about employment of the population, creates additional value orientations and motives, contributes to the overall welfare of the population and reducing social tension in society. In General, this area of active employment policy in rural areas requires more attention and support from government agencies.

\section{References}

Avarskij, N., Gasanova, H., Gadzhieva, A. (2016) Kooperaciyakak forma razvitiya sistemy tovarodvizheniya na mirovom rynke moloka i molochnoj produkcii [Cooperation as a form of development of the commodity distribution system on the world market of milk and dairy products]. Ekonomika sel'skogo hozyajstva Rossii - Agricultural Economics of Russia]. 9, 74-79 [in Russian].

Andarova, R.K., Zhadigerova, G.A., Narkulova Sh.A. (2019 ) Zhurtshylyk sharuashylygynyn uzhymdyk kasiporyndarmen ozara karym-katynastaryn damytudyn zholdary [Ways of development of the relationship between farms from collective enterprises] Karagandy universitetinin habarshysy - Bulletin of Karaganda University],4, 247-257[in Kazakh].

Yesbolova, A.Y., Ibraimova, S.S., Mergenbaeva, A.T. (2016). Econometric analysis of the poultry industry development in Kazakhstan. Indian Journal of Science and Technology, 11, 1-8. Doi:10.17485/ijst/2016/v9i20/94489 
Yesbolova, A.Y., Mergenbaeva, A.T., Abdikerimova, G.I., Kydyrova, Z.S.(2016). Issues and prospects of poultry industry development in Kazakhstan. Journal of Advanced Research in Law and Economics,7, 685 697.Doi:10.14505/jarle.v7.3(17).26

Yesbolova, A., Maciejczak, M., Ibraimova, S., Akhelova, A. (2016). System based Development of the Poultry Sector in Kazakhstan in Mid Term Perspective. Journal of Applied Economic Sciences, 11, 804-811. Retrieved from

http://www.scopus.com/inward/record.url?eid=2-s2.0-84991716856\&partnerID=MN8TOARS

Yesbolova, A., Ibraimova, S.S., Zhadigerova, G.A., Sametova, G.E. (2014).The ways to develop the cattle sector in Kazakhstan. European Applied Sciences, 3, 155-157.

Fabio, F., Gavrilescu, A., (2012). Special Issue Dedicated to Environmental Biotechnology for the Knowledge-Based $\mathrm{BIO}$ and Green Economy. Environmental Engineering and Management, 11(10), 1731-1732.

Grigoruk, V.V., Umbitaliev, N.A. (2017) Lichnoe podsobnoe hozyajstvo na sovremennom etape razvitiya Kazahstana [Personal subsidiary farming at the present stage of development of Kazakhstan] Problemy agrorynka - Problems of agrifood markets, 1, 34-40 [in Russian].

Hachataryan, M., Kazaryan, M. (2020) Osobennostirazvitiyairegulirovaniyamalyh form hozyajstvovaniya v sel'skomhozyajstveArmenii [Features of development and regulation of small-scale farming in Armenia]. Retrieved from www.fao.org/fileadmin/user_upload/reu/europe/.../Arm_ru.pdf. 30.06 .2020 [in Russian].

Kojtanova, A.Zh., Zholmuhanova, A.Zh., Al'peisova, Sh.E. (2017) Auyl sharuashylygynda personaldyn eңbek onimdiligin arttyru zholdary [Ways to increase staff productivity in agriculture] Karagandy universitetinin habarshysy - Bulletin of Karaganda University, 2(86), 179-186 [in Kazakh].

Myrzaliev, B.S., Shinet, G.G. (2016) Zhurtshylyk sharuashylyktarynyn roli zhane olardyn Ontustik Kazakstan oblysyndagy damu erekshelikteri [Role of population farms and features of their development in South Kazakhstan region]. Agrarlyk naryk problemalary - Problems of agrifood markets, 3, 67-73 [in Kazakh].

Mizanbekova, S., Uspanova, M., Kunanbaeva, D. (2018), Food supply security : the case of Eaeu member-states Entrepreneurship Education, 21(3), 1-13

Shinet, G.G., Myrzaliev, B.S., Ydyrys, S.S. (2016) Conceptual Approaches to the Study of Nature of Private Ownership of Private Subsidiary Farming during Post-Socialist Transformation in Agricultural Sector. Journal of Advanced Research in Law and Economics, (Volume VII, Spring), 2(16): 350 - 362, Doi: 10.14505/jarle.v7.2(16).19.

Shinet, G.G. (2015) Lichnye podsobnye hozyajstva Respubliki Kazahstan: sushchnost', nyneshnee sostoyaniei perspektivy razvitiya [Personal subsidiary farms of the Republic of Kazakhstan: the essence, current state and prospects of development] Informacionnoe obespechenie effektivnogo upravleniya deyatel'nost'yu ekonomicheskih sub"ektov: materialy VI mezhdunarodnoj nauchno-prakticheskoj konferencii - Information support for effective management of economic entities: proceedings of the VI international scientific and practical conference, Krasnodar, 2015, P. 587-592. [in Russian].

Valiev, I., Koshlich, Y., Mussayeva, D. (2018). Management innovations for enterprise development and effective decision making. Journal of Entrepreneurship Education, 21, 189-197.

\section{Г.Ғ. Шінет, Г.А. Жадигерова, А.Е. Есболова, Р.К. Андарова, Э.Е. Жусипова \\ Ауыл халқын жұмыспен қамту мәселелерін шешудегі жұртшылық шаруашылығының рөлі мен дамуы}

\footnotetext{
Аңдатna

Maқ̧саты: Мақаланың мазмұны ауыл шаруашылығының жұртшылық шаруашылығы деп аталатын шаруашылық жүргізуші шағын нысанды санатының әлеуметтік мәселе - жұмыспен қамтуды шешуде үлес қосатындығына арналған.

Әдісі: Қазақстан Республикасы ауыл шаруашылығындағы жұртшылық шаруашылығының әрекет етуін және оның бүгінгі таңдағы ауыл шаруашылық өнімдерді өндірудегі үлес салмағы қарастырылған. Жұртшылық шаруашылықтарының әрекет ету принципіне, сандық көрсеткіштеріне, ауыл шаруашылық өнім өндірісіндегі үлес салмағы сипатталған. Ауыл халқының өзін-өзі жұмыспен қамтудағы жұртшылық шаруашылығы туралы көптеген ғалымдардың зерттеу жұмыстарын жүргізгендігі жайлы дәйектер мақала мазмұнында көрсетілген.

Kopblmblндbl: Жұртшылық шаруашылықтары ауыл халқының жұмыспен қамтылуында өз үлес салмағына ие екендігін, ауыл шаруашылығында қалыптасқан ахуалмен түсіндірген. Алайда ауыл халқының жұмыспен қамтуды зерттеуге арналған тұтас мақсатты кешенді зерттеулердің қалыптаспағандығын алға тартқан. Сол себепті осы тақырыпты зерттеп, талдау жасаулар негізділігі келтірілген.

Тұжырымдама: Сандық мәліметтерді ұсына отырып, жұртшылық шаруашылығының ауыл шаруашылық өнім өндірісіндегі салмақты үлеске ие екендігі дәлелденді. Сол арқылы ауыл халқының жұмыспен қамтылып, өз табыстарын тауып жатқандығын байқауға болатындығын түсіндірген. Бірқатар өзекті мәселелер айтылып, шешу жолдарын табудың маңыздылығы негізделген.
}

Кілm сөздер: ауыл шаруашылығы, ауыл шаруашылық кәсіпорын, жұртшылық шаруашылығы, жеке қосалық шараушылық, шаруа (ферма) қожалықтары, өзін-өзі жұмыспен қамту, жұмыспен қамтылғандар, ауыл шаруашылық кәсіпорындар, мал шаруашылығы, өсімдік шаруашылығы. 


\section{Г.Ғ. Шінет, Г.А. Жадигерова, А.Е. Есболова, Р.К. Андарова, Э.Е. Жусипова \\ Роль и развитие хозяйств населения в решении вопросов занятости населения сельской местности}

\section{Аннотация}

Цель: В содержании статьи рассмотрено хозяйство населения как категория сельского хозяйства, которая вносит свой вклад в решение социальной проблемы - занятости населения.

Meтодbl: Изучены функционирование хозяйств населения в сельском хозяйстве Республики Казахстан и его удельный вес в производстве сельскохозяйственной продукции на сегодняшний день. Описаны принцип действия, количественные показатели хозяйств населения, удельный вес в производстве сельскохозяйственной продукции. В содержании статьи приведены мысли ученых о проведении многочисленных исследований по вопросам самозанятости населения сельского хозяйства.

Pезультаты: Отражен удельный вес хозяйств населения в занятости сельского населения по сложившейся ситуации сельской местности. Однако не сформировались целостные целевые комплексные исследования для исследования занятости сельского населения. В этой связи приведена обоснованность изучения и анализа данной темы.

Bblвoдbl: Представляя количественные данные, общественность доказала, что сельское хозяйство имеет весомую долю в производстве сельскохозяйственной продукции. Тем самым объясняется, что сельское население является самозанятым и зарабатывает в хозяйствах самостоятельно.

Ключевые слова: сельское хозяйство, агропромышленный комплекс, личное подсобное хозяйство, хозяйство населения, фермерское хозяйство, кооператив, самозанятость, самозанятые, сельскохозяйственные предприятия, скотоводство, растениеводство.

\section{References}

Аварский Н. Кооперация как форма развития системы товародвижения на мировом рынке молока и молочной продукции / Н. Аварский, Х. Гасанова, А. Гаджиева // Экономика сельского хозяйства России. — 2016. - С. 74-79.

Андарова Р.К. Жұртшылық шаруашылығының ұжымдық кәсіпорындармен өзара қарым-қатынастарын дамытудың жолдары / Р.К. Андарова, Г.А. Жадигерова, Ш.А. Наркулова // Қарағанды университетінің хабаршысы. - 2019. - № 4. - Б. 247-257.

Yesbolova, A.Y., Ibraimova, S.S., Mergenbaeva, A.T. Econometric analysis of the poultry industry development in Kazakhstan / A.Y. Yesbolova, S.S. Ibraimova, A.T. Mergenbaeva// Indian Journal of Science and Technology. 2016. - № 11. - P. 1-8.

Yesbolova, A.Y., Mergenbaeva, A.T., Abdikerimova, G.I., Kydyrova, Z.S. Issues and prospects of poultry industry development in Kazakhstan / A.Y. Yesbolova, A.T. Mergenbaeva, G.I. Abdikerimova, Z.S. Kydyrova // Journal of Advanced Research in Law and Economics.- 2016. — № 7. - P. 685 - 697.

Yesbolova, A., Maciejczak, M., Ibraimova, S., Akhelova, A. System based Development of the Poultry Sector in Kazakhstan in Mid Term Perspective / A. Yesbolova, M. Maciejczak, S. Ibraimova, A. Akhelova // Journal of Applied Economic Sciences. — 2016. — № 11. - P. 804-811.

Yesbolova, A., Ibraimova, S.S., Zhadigerova, G.A., Sametova, G.E. The ways to develop the cattle sector in Kazakhstan / A.Yesbolova, S.S.Ibraimova, G.A.Zhadigerova, G.E. Sametova // European Applied Sciences. — 2014. — № 3. - P. 155-157.

Fabio, F., Gavrilescu, A. Special Issue Dedicated to Environmental Biotechnology for the Knowledge-Based BIO and Green Economy / F. Fabio, A. Gavrilescu // Environmental Engineering and Management. — 2012. — Vol.11. № 10. - Р. 1731-1732.

Григорук В.В. Личное подсобное хозяйство на современном этапе развития Казахстана / В.В. Григорук, Н.А. Умбиталиев // Проблемы агрорынка. — 2017. — № 1. — С. 34-40.

Хачатарян М. Особенности развития и регулирования малых форм хозяйствования в сельском хозяйстве Армении / М. Хачатарян, М. Казарян // Продовольственная и сельскохозяйственная Организация Объединенных Наций. - 2020.

Койтанова А.Ж. Ауыл шаруашылығында персоналдың еңбек өнімділігін арттыру жолдары / А.Ж. Койтанова, А.Ж. Жолмуханова, Ш.Е. Альпеисова // Қарағанды университетінің хабаршысы.- 2017. — № 2. — Б. 4-9.

Мырзалиев Б.С., Шінет, Г.Г. Жұртшылық шаруашылыктарының рөлі және олардың Оңтүстік Қазақстан облысындағы даму ерекшеліктері / Б.С. Мырзалиев, Г.Г. Шінет // Аграрлық нарық проблемалары. — 2016. — № 3. - Б. 67-73

Mizanbekova, S., Uspanova, M., Kunanbaeva, D. Food supply security: the case of Eaeu member-states Entrepreneurship Education / S. Mizanbekova, M. Uspanova, D. Kunanbaeva // Problems of AgriMarket // 2018. -Vol 21. № 3. - P. 1-13

Shinet, G.G., Myrzaliev, B.S., Ydyrys, S.S. Conceptual Approaches to the Study of Nature of Private Ownership of Private Subsidiary Farming during Post-Socialist Transformation in Agricultural Sector / G.G. Shinet, 
B.S Myrzaliev, S.S. Ydyrys // Journal of Advanced Research in Law and Economics. — 2016. — Volume VII. № 2. - Р. $350-362$.

Шінет Г.Ғ. Личные подсобные хозяйства Республики Казахстан: сущность, нынешнее состояние и перспективы развития / Г.Ғ. Шінет // Информационное обеспечение эффективного управления деятельностью экономических субъектов. - 2015. - С. 587-592.

Valiev, I., Koshlich, Y., Mussayeva, D. Management innovations for enterprise development and effective decision making / I. Valiev, Y. Koshlich, D. Mussayeva // Journal of Entrepreneurship Education. — 2018. — Vol. 21. — ISSN: 1098-8394 